\title{
Co-creating a learning culture - Co-créer une culture d'apprentissage
}

Jacinthe I. Pepin

Université de Montréal, jacinthe.pepin@umontreal.ca

Florence Myrick

amyrick@ualberta.ca

Follow this and additional works at: https://qane-afi.casn.ca/journal

\section{Recommended Citation}

Pepin, Jacinthe I. and Myrick, Florence (2015) "Co-creating a learning culture - Co-créer une culture d'apprentissage," Quality Advancement in Nursing Education - Avancées en formation infirmière: Vol. 1: Iss. 3, Article 1.

DOI: https://doi.org/10.17483/2368-6669.1066

This Editorial is brought to you for free and open access by Quality Advancement in Nursing Education - Avancées en formation infirmière. It has been accepted for inclusion in Quality Advancement in Nursing Education - Avancées en formation infirmière by an authorized editor of Quality Advancement in Nursing Education - Avancées en formation infirmière. 


\section{Co-creating a learning culture}

"A cultural construct like language can change the way people see the world. [...] In this way, culture imprints some patterns in our brains and dissolves others." (Brooks, 2011, p. 151-152)

Today, in this global age, there inheres in nursing education a responsibility to design curricula in such a way so as to prepare nurses who are competent in providing and promoting consistent quality of care for every person, family or group in various contexts and diverse populations. The diversity in populations encompasses age, ethnicity, gender, language, life style, mental and physical capabilities, religious or spiritual beliefs, and socioeconomic status. Faculty thus need to ensure that future graduates are introduced to a variety of health care organizations not only as potential clinical practice and research milieus but also as ongoing environments of learning. Invariably, each person, family, group, and organization is embedded within a specific culture by which they are greatly influenced and in which they contribute to socialize others. Similarly, nursing programs are themselves simultaneously embedded not only in their own particular culture but also in that of academe which too is a distinctive cultural context within a larger politico-economic system.

In keeping with the anthropologist Geertz (1973), we define culture as a system of significances. And, together with authors who are published in this issue of QANE/ AFI, we suggest that advancing quality nursing education includes challenging some premises intrinsic to our academic/ health, research/ clinical cultures, with respect for each while co-creating a pervasive learning culture. Indeed, in their quest to educate for complexity, Rosenau et al. present a collaborative curricular transformation focusing on context-relevance and integrative learning, while Symonds-Brown and Milner describe how space is provided for students to develop leadership with the assistance of collaborative partnerships. Meherali et al. present the results of a research study linking critical thinking dispositions and research utilization. These exemplars of reducing barriers between separate cultures can lead to the co-creation of an overarching learning culture (or paradigm) by and for students, educators and nurses in the various practice domains so that spaces for co-learning through practices become ingrained in the nursing profession. Amidst complexity, these spaces can serve to strengthen further the nursing contribution in the design of knowledge based care in a more humanistic health care system. For their part, Berry calls for building a culture of scholarship in every nursing education institution while Ouellet and Mukamurera's research results call for a culture of continued learning for quality elder care.

The "Final Report of the Truth and Reconciliation Commission of Canada" (2015) was the impetus for the conducting of our interview with Dr. Lisa Bourque-Bearskin, an Indigenous Nurse Educator. From her point-of-view, a relational pedagogy has to be embraced by people in all sites of learning, so that the understanding of human beings and the honoring of diversity and cultures can be authentically nurtured.

Hence, we can see that nurse educators are concerned with fostering the development of graduates' cultural competence. Indeed, some are already tapping into the diversity of interdependent education and health institutions' cultures. What remains to be co-created and imprinted in the reality of nursing is a learning culture focused on the learner's perspective in concert with each person, family, group, student, and organization with whom we are dialoguing; on creating spaces for co-learning in practice sites; and on honoring critique as a respectful gesture towards human endeavor. 
Taking the opportunity of this editorial, we sincerely thank the authors and reviewers who, through their scholarly work, make possible this online peer reviewed Journal on the advancement of nursing education since its beginning in 2014. We are grateful and welcome any comments on the content and any suggestions for expanding our pool of reviewers (sbond@casn.ca).

\section{Co-créer une culture d'apprentissage}

«Une construction culturelle comme la langue peut changer la façon dont les gens voient le monde. [...] De cette façon, la culture empreigne quelques modèles dans nos cerveaux et en dissout d'autres. » [Traduction] (Brooks, 2011, p. 151-152)

Aujourd'hui, à l'ère de la mondialisation, une responsabilité inhérente à la formation en sciences infirmières est celle d'élaborer des programmes qui préparent des infirmières compétentes dans la prestation et la promotion de soins de qualité constante pour chaque personne, famille ou groupe dans divers contextes et populations. La diversité des populations englobe les différents âges, origines ethniques, sexes, langues, styles de vie, capacités mentales et physiques, croyances religieuses ou spirituelles et statuts socioéconomiques. Le corps professoral doit donc s'assurer que les futures diplômées soient exposées à une variété d'organisations de santé, non seulement en tant que milieux éventuels de pratique et de recherche, mais aussi en tant qu'environnements d'apprentissage continu. Invariablement, chaque personne, famille, groupe et organisation est ancré(e) dans une culture précise par laquelle il ou elle est fortement influencé(e) et dans laquelle il ou elle contribue à socialiser les autres. De même, les programmes de sciences infirmières s'inscrivent non seulement dans leur propre culture, mais aussi dans celle du monde universitaire, qui est également un contexte culturel particulier au sein d'un système politico-économique plus large.

À l'instar de l'anthropologue Geertz (1973), nous définissons la culture comme un système de significations. De concert avec les auteurs dont les articles sont publiés dans ce numéro de QANE/AFI, nous suggérons que l'avancement de la qualité de la formation infirmière, passe par l'examen de certains principes fondateurs de nos cultures universitaire ou de santé, de recherche ou de clinique, dans le respect de chacun, tout en co-créant une forte culture d'apprentissage. En effet, dans leur quête de former pour la complexité, Rosenau et coll. ont présenté la transformation collaborative de leur programme qui met l'accent sur l'apprentissage en contexte et intégré, alors que Symonds-Brown et Milner décrivent comment des partenariats de collaboration peuvent créer des occasions pour les étudiantes de développer leurs capacités de leadership. De leur côté, Meherali et coll. présentent les résultats d'une recherche reliant les dispositions à la pensée critique et l'utilisation de la recherche. Ces exemples de réduction de barrières entre cultures distinctes peuvent mener à la co-création d'une méta-culture d'apprentissage (ou paradigme) par et pour les étudiantes, les formatrices et les infirmières des divers domaines de pratique, de sorte que des espaces de co-apprentissage à partir de la pratique s'enracinent dans la profession infirmière. Au milieu de la complexité, ces espaces peuvent servir à renforcer encore davantage la contribution des infirmières à l'élaboration de soins fondés sur des connaissances dans un système de santé plus humaniste. Pour sa part, Berry encourage le développement d'une culture d'avancement des connaissances dans tous les établissements de formation en sciences infirmières, alors que les résultats de la recherche de Ouellet et Mukamurera soutiennent une culture d'apprentissage continu pour des soins de qualité aux personnes âgées. 
Le Rapport final de la Commission de vérité et réconciliation du Canada (2015) a inspiré la réalisation de notre entrevue avec la professeure Lisa Bourque-Bearskin, une infirmière autochtone. De son point de vue, une pédagogie relationnelle doit être adoptée par les personnes dans tous les sites d'apprentissage afin que la compréhension des êtres humains et le respect de la diversité et des cultures puissent être authentiquement encouragés.

Ainsi, nous constatons que les infirmières formatrices s'affairent à soutenir le développement de la compétence culturelle des futures diplômées. En effet, certaines puisent déjà dans la diversité des cultures interdépendantes des institutions d'éducation et de santé. Ce qui reste à co-créer et à imprimer dans la réalité des sciences infirmières est une culture d'apprentissage axée sur la perspective de l'apprenante de concert avec chaque personne, famille, groupe, étudiante et organisation avec qui nous entretenons des dialogues, est la création d'espaces de co-apprentissage dans les lieux de pratique et l'accueil de la critique comme un geste de respect envers le dépassement humain.

Nous saisissons l'occasion présentée par cet éditorial pour remercier les auteurs et les réviseurs qui, par leurs travaux d'érudition, rendent possible cette revue, dont les articles portant sur les avancées en formation infirmière sont revus par les pairs depuis l'inauguration en 2014. Nous leur sommes reconnaissantes et nous encourageons tout commentaire sur le contenu ainsi que des suggestions pour élargir notre bassin de réviseurs (sbond@casn.ca).

Cordialement / Respectfully,

Corédactrices en chef, Co-Editors-in-Chief,

Jacinthe Pepin, inf. Ph. D., Faculté des sciences infirmières, Université de Montréal

Florence Myrick. RN, PhD, Faculty of Nursing, University of Alberta

\section{References / Références}

Brooks, D. (2011). The Social Animal. The Hidden Sources of Love, Character, and Achievement. New York: Random House.

Geertz, C. (1973). The interpretation of cultures: selected essays. New York: Basic Books.

Truth and Reconciliation Commission of Canada (2015). Honouring the Truth, Reconciling for the Future, Final Report. Online:

http://www.trc.ca/websites/trcinstitution/File/2015/

Honouring_the_Truth_Reconciling_for_the_Future_July_23_2015.pdf. 